\title{
PEMBATALAN 3.143 PERATURAN DAERAH: Satu Analisis Singkat
}

\author{
Leo Agustino \\ Fakultas Ilmu Sosial dan Ilmu Politik \\ Universitas Sultan Ageng Tirtayasa (Untirta) \\ email: leoagustino@gmail.com
}

\begin{abstract}
ABSTRAK
Artikel ini membahas mengenai otonomi daerah dan peraturan daerah bermasalah. Sejak otonomi dilaksanakan, peraturan daerah yang bermasalah tumbuh lebih buruk daripada masa sebelumnya. Akibatnya, pelayanan menjadi tidak prima, pungutan liar (pungli) terjadi, dan korupsi menjadi hal yang biasa. Oleh karena itu, pemerintah pusat mengambil inisiatif untuk menyelesaikan masalah ini dengan membatalkan peraturanperaturan daerah bermasalah di seluruh Indonesia yang berjumlah 3.143.
\end{abstract}

\section{Kata kunci: Peraturan daerah, Otonomi, Pembatalan}

\begin{abstract}
This article discusses regional autonomy and problematic local regulations. Since local autonomy has been implemented, problematic local regulations have grown worse than ever before. As an impacts, public services are not proper, illegal levies occur, and corruption becomes commonplace. For that reason, the central government took the initiative to resolve these problems by terminated problematic local regulations in Indonesia, that totaling 3,143.
\end{abstract}

Keywords: local regulation, Autonomy, Terminate

\section{PENDAHULUAN}

Sejak diundangkannya Undang-undang No. 22 tahun 1999 tentang Pemerintahan Daerah dan Undang-undang No. 25 tahun 1999 tentang Perimbangan Keuangan Pusat dan Daerah, beberapa kewenangan keuangan (daerah) dilaksanakan oleh pemerintah daerah. Mulai saat itu pemerintah daerah mempunyai kewenangan yang besar untuk merencanakan, merumuskan, melaksanakan, serta mengevaluasi kebijakan yang sesuai dengan keperluan dan tuntutan masyarakat. Sejak saat itu pulalah pemerintah daerah tidak lagi sekadar sebagai pelaksana operasional regulasu yang ditentukan oleh pemerintah pusat (top-down policy), tetapi telah menjadi agen penggerak pembangunan di tingkat daerah.

Melalui pelaksanaan otonomi daerah, apapun yang dibuat oleh pemerintah daerah dapat dengan mudah dinilai oleh masyarakatnya sendiri. selain itu, pada prinsipnya otonomi daerah memberikan 
kesempatan yang besar bagi pembangunan masyarakat di tingkat lokal, pemerataan pembangunan antar-wilayah, dan membuka peluang baru bagi perbaikan kegiatan ekonomi.

Namun, merujuk pada kondisi yang terjadi, pelaksanaan otonomi daerah masih dirasa jauh dari harapan. Ini karena masih banyak penyimpangan yang terjadi di berbagai bidang. Salah satunya, pemerintah daerah kerap melakukan peningkatan pungutan di daerah sehingga memperlambat iklim usaha. Alasan yang diajukan oleh pemerintah daerah adalah untuk membiayai pembangunan daerah (dalam arti kata lain, mengisi Pendapatan Asli Daerah). Padahal jika iklim usaha di daerah menjadi lebih kondusif, maka akan muncul multiplier-effects yang diharapkan seperti investor yang menanamkan modalnya di daerah sehingga membuka lapangan pekerjaan di daerah dan lainnya.

Terkait dengan regulasi daerah yang diintensifikasi dan diekstensifikasi, maka tidak heran apabila hampir semua komoditas ekonomi yang dihasilkan oleh daerah dijadikan objek pungutan. Bahkan, komoditas yang melintas di suatu daerah tidak jarang dijadikan objek pajak, sehingga bukan hal yang mustahil apabila satu komoditas yang kebetulan harus melintas dua atau tiga daerah kabupaten/kota—sejak dari produsen ke konsumen-mereka harus membayar pungutan dua atau tiga kali lebih besar dibandingkan era sebelumnya. Kondisi obyektif inilah yang mendorong Kementerian Dalam Negeri (Kemendagri) sepanjang tahun 2002 hingga tahun 2009 melakukan pembatalan 2.246 peraturan daerah (Perda). ${ }^{1}$ Tidak berhenti di sana, antara tahun 2010 hingga tahun 2014 pun Kemendagri melakukan pembatalan sebanyak 1.501 Perda, kemudian November hingga Mei 2015 ada 139 peraturan daerah dibatalkan. ${ }^{2}$ Total hingga Mei 2015, setidaknya, sebanyak 7.029 Perda telah dibatalkan.

Pembatalan Perda kembali dilakukan oleh Kemendagri pada Juni 2016, di mana pada kesempatan tersebut Presiden Joko Widodo (kerap disapa Jokowi) membacakan sendiri 3.143 Perda yang dibatalkan. ${ }^{3}$ Dari 3.000 lebih Perda yang dibatalkan, 1.765 di antaranya adalah Perda Provinsi dan Kabupaten/Kota serta $100 \quad$ Peraturan/Keputusan Menteri Dalam Negeri dan yang dicabut/direvisi oleh Menteri Dalam Negeri (Mendagri); dan 1.267 Perda Kabupaten/Kota yang dicabut/direvisi oleh gubernur

\footnotetext{
${ }^{1}$ Data olahan penulis.

${ }^{2}$ Data olahan penulis.

${ }^{3}$ Merujuk daftar yang diterbitkan oleh Kemendagri, sebenarnya pembatalan Perda/Perkada dan Permendagri bukan 3.143, tetapi 3.142. Ini karena Perda Kabupaten Asahan No. 8 tahun 2009 tentang Pengelolaan Baran Milik Daerah dicatat rangkap yakni pada No. 72 dan 73 dalam Daftar Pembatalan Perda/Perkada dan Peraturan Menteri Dalam Negeri yang Dibatalkan.
} 
(Kementerian Dalam Negeri

Republik Indonesia 2016).

Terdapat empat perihal yang menyebabkan Perda dibatalkan: (i) Perda dan Perkada tersebut menghambat investasi (perizinan, retribusi, jasa usaha, IMB, sumbangan pihak ke-3, dan lainnya); (ii) Perda dan Perkada tersebut bertentangan dengan undang-undang yang lebih tinggi dan kepentingan umum; (iii) Perda dan Perkada tersebut bertentangan dengan UU No. 23 tahun 2014 tentang Pemerintahan Daerah dan Putusan Mahkamah Konstitusi (sumber daya air, menara telekomunikasi, BUMD, dan pengalihan urusan); dan (iv) Perda dan Perkada lainnya yang dirasa tidak perlu karena merupakan norma awam yang berlaku di masyarakat. ${ }^{4}$

\section{OTONOMI DAERAH:}

\section{ILUSTRASI KONSEPTUAL}

Otonomi secara etimologi berasal dari kata auto dan nomos yang berarti sendiri dan peraturan (atau perintah). Merujuk pada dua kata tersebut, maka secara sederhana otonomi dapat diartikan sebagai 'peraturan yang dibuat oleh satu entitas (pemerintahan) tersendiri' atau 'memerintah sendiri' (Leo Agustino 2014: 13). Kajian klasik Hoggart (1981) menyatakan otonomi

${ }^{4}$ Wawancara dengan Direktur Produk Hukum Daerah, Direktorat Jenberal Otonomi Daerah, Kementerian Dalam Negeri, Dr. Kurniasih, pada 2 Juni 2016. harus dipahami sebagai sebuah interaksi antara pemerintah yang berada lebih tinggi kedudukannya dengan pemerintah yang berada di bawahnya. Dalam konteks ini, otonomi mesti dipahami sebagai independence of localities. Sejalan dengan Hoggart (1991), Sammoff (1990: 515) menyatakan bahwa otonomi sebagai transferred power and authoriry over decision making to local units are the core of autonomy.

Dua argumen tersebut tidak disanggah oleh Rosenbloom (1993) yang menjelaskan otonomi sebagai wujud penyerahan kuasa pada pemerintah yang lebih rendah tingkatannya untuk mengatur wilayahnya secara bebas tanpa ada campur tangan dari pemerintah pusat. Bahkan Kirby (Dlm. Ali 2002) memberi definisi otonomi daerah sebagai kebebasan pemerintah daerah untuk berperan dalam menentukan tujuan, kebijakan, dan membuat keputusan pembangunan berdasar keperluan masyarakat setempat.

Tidak jauh berbeda, EscobarLemmon (2000) menyatakan otonomi sebagai pemindahan otoritas, fungsi, dan tanggung-jawab untuk memformulasi kebijakan dan keputusan dari pemerintah pusat pada pemerintah daerah. Atas dasar konsep tersebut, maka ada bidang kuasa pemerintah daerah untuk membuat program dan peraturan sesuai keadaan wilayahnya. Ole 
karena itu, otonomi merupakan antitesis dari sentralisasi politik. Oleh karena itu, otonomi seringkali dipadankan dengan desentralisasi. Karena keduanya menyiratkan pelembagaan kekuasaan dari pemerintah pusat kepada pemerintah daerah, maka beberapa sarjana seperti Smith (1985: 18) menyatakan desentralisasi sebagai:

... involves the delegation

of power to lower levels in a territorial hierarchy;

.... Decentralization may

be clearly distinguished

from the dispersal of headquareters branches from the capital city, as when part of a national ministry is moved to provincial city to provided employment there.

Seabright (1996:

memberikan pendangan penjelas mengenai kekuasaan pusat dan daerah dengan menegaskan bahwa kewajiban pemerintah pusat hanyalah to inspect, monitor, and where necessary offer technical advice, support supervision, and training within their respective sectors; tidak lebih. Atas dasar pengertian ini, keputusan dan tindakan pimpinan daerah diarahkan pada pilihan-pilihan yang berkembang di daerah berdasarkan keperluan bagi mengembangkan kemampuan politik dan ekonomi masyarakat. Oleh karena itu, dapat dikatakan bahwa otonomi daerah adalah instrumen bagi mematangkan demokrasi politik, ekonomi, dan partisipasi rakyat di level lokal tanpa harus menanggalkan hirarki yang melekat dalam konteks otonomi itu sendiri. Dalam arti kata lain, untuk konteks negara kesatuan seperti Indonesia, maka konteks hirarki yang melakat pada pemeirntah daetah tidak bisa dianggap enteng karena daerah merupakan bagian yang integral dalam pemerintahan yang berdaulat. Merujuk kerangka inilah, otonomi daerah ditempatkan.

\section{KONDISI PASCA \\ PEMBATALAN PERDA DAN PEREKONOMIAN DAERAH}

Pembatalan 3.143 Perda pada 13 Juni 2016 mendapat banyak reaksi dari pelbagai pihak. Ketua MPR, Dr. Zulkifli Hasan misalnya, sangat setuju dengan pembatalan Perda. Alasannya, kalau Perda tersebut menghambat investasi dan menyulikan masyarakat kenapa harus tetap dipertahankan (http://warta.co/ketua-mpr-sepakatpembatalan-perda-olehpemerintah.html 25 Desember 2016). Tetapi, sebagian besar menanggapi pembatalan Perda secara negatif. Kepala Dinas Pendapatan Kota Medan misalnya, menyatakan bahwa pembatalan Perda Kota Medan akan berimbas pada hilangnya potensi pendapatan asli daerah (PAD) hingga Rp. 35 miliar per tahun. Menurutnya 
lebih lanjut, hilangnya potensi tersebut akan berimplikasi pada belanja proyek (http://www.koransindo.com/news.php? $r=5 \& n=4 \&$ date =2016-06-23 25 Desember 2016).

Hal yang sama juga dinyatakan Kepala Dinas Pengelolaan Keuangan dan Aset Daerah (PPKAD) Pemerintah Kabupaten Simalungun, Mixnon Andreas Simamora, yang sudah menghitung-hitung, setidaknya terdapat PAD yang berkurang hingga Rp. 50 miliar lebih. Lebih lanjut ia menyatakan bahwa target PAD Kabupaten Simalungun dari pajak daerah (termasuk di dalamnya Pajak Bumi dan Bangunan (PBB)) tahun 2016 ini sebesar Rp. 50 miliar, pajak retribusi jasa usaha sebesar Rp. 1 miliar, dan pajak retribusi jasa umum sebesar Rp. 5,5 miliar (http://www.koran-

sindo.com/news.php?r=5\&n=4\&date = 2016-06-23 26 Desember 2016). Tidak jauh berbeda dengan Kota Medan dan Kabupaten Simalungun, Bupati Sergai, Soekirman, mengatakan hal yang lebih kurang sama bahwa dari 8 Perda yang dibatalkan oleh Kemendagri, PAD Kabupaten Sergai diperkirakan akan hilang mencapai Rp. 58,7 miliar (http://www.koran-sindo.com/ news.php? $\mathrm{r}=5 \& \mathrm{n}=4 \&$ date $=2016-06-$ 2326 Desember 2016).

Demikian pula halnya dengan Surakarta, akibat pencabutan atau pembatalan Perda di Surakarta menyebabkan hilangnya pendapatan daerah hingga Rp. 227,7 miliar (http://berita.suaramerdeka.com/smc etak/pajak-ratusan-miliar-rupiah-

bisa-hilang/ 26 Desember 2016). Sementara itu di Ternate, Wakil Ketua DPRD Kota Ternate, Mubin A Wahid, setuju dengan perihal berkurangnya PAD akibat pembatalan Perda oleh Kemendagri pada pertengahan Juni 2016. Ia mengatakan 5 Perda Kota Ternate yang dibatalkan sangat mempengaruhi pendapatan daerah, malah akan merugikan PAD Kota Ternate hingga Rp. 11 miliar (http://www.suara.com/news/2016/0 6/25/102829/ternate-rugi-rp11miliar-akibat-pembatalan-perda

Desember 2016).

Kendati nada negatif lebih banyak dilntakna oleh daerah, tapi suara positif daerah pun terdengar pula. Misalnya, Gubernur Sumatera Utara, Tengku Erry Nuradi, menyatakan walau ada 6 Perda Provinsi Sumatera Utara yang dicabut oleh Kemendagri, tetapi ia yakin hal tersebut tidak akan merugikan PAD Sumut. Malah ia menjelaskan beberapa Perda yang dibatalkan tersebut memang harus dianulir karena menghambat iklim investasi (http://www.koransindo.com/news.php? $\mathrm{r}=5 \& \mathrm{n}=4 \&$ $\underline{\text { date }=2016-06-23} 27$ Desember 2016).

Merujuk pada keterangan di atas, maka reaksi dan keluhan daerah atas pembatalan Perda lebih banyak mengarah pada kekhawatiran mereka 
atas hilangnya potensi $\mathrm{PAD}$, sedikit yang menyinggung legalitas Kemendagri dalam pembatalan Perda. Persoalannya sekarang, apakah benar PAD di daerah akan berkurang? Dan, bagaimanakah mengelola daerah dalam iklim yang berubah seperti ini (pasca pembatalan Perda)?

Menjawab pertanyaan pertama, apakah benar PAD di daerah akan berkurang? Tentu ada dampak dari pembatalan Perda pada PAD, namun tidak sebesar yang diberitakan oleh daerah-hingga belasan dan puluhan miliar. ${ }^{5}$ Ini karena Dana Bagi Hasil (DBH) akan tetap besar. Pernyataan beberapa pejabat daerah terkait hilangnya potensi daerah hingga puluhan miliar merupakan reaksi sesaat akibat dari pembatalan Perda yang dirasa tibatiba (sebab mereka merasa tidak dilibatkan dalam proses pembatalan tersebut, malah Perda yang dibatalkan oleh Kemendagri pernah

${ }^{5}$ Merujuk Notulensi Rapat Direktur Jenderal Otonomi Daerah dan Direktorat Produk Hukum Daerah tanggal 27 Juni 2016 disebutkan bahwa implikasi besaran pengurangan PAD akibat pembatalan Perda, adalah sebagai berikut: (i) Untuk Kategori Retribusi Jasa Umum, diperkirakan pengurangan PAD rata-rata sebesar 10-15\%; (ii) Untuk Kategori Pelayanan Publik, diperkiran pengurangan PAD sebesar 5-7\%; (iii) Untuk Pengalihan Urusan, diperkirakan pengurangan PAD untuk Kab/Kota 0\% (karena pengalihan urusan belum diikuti dengan pengalihan pendapatan dari hasil pajak dan retribusi, yang baru akan beralih bilamana ada perubahan Undang-undang No. 28 tahun 2009 tentang Pajak Daerah dan Retribusi Daerah). mereka diskusikan sebelumnya dengan Biro Hukum Kemendagri). Oleh karena itu, reaksi yang dapat dilakukan hanyalah menyodorkan besaran hilangnya potensi PAD yang berimplikasi pada pembangunan di daerah. Dan kesalahan ini (hilangnya potensi PAD yang berdampak pada pembangunan), menurut mereka, patut ditimpakan pada Kemendagri.

Pernyataan daerah itu tentu belum bisa dikaunter dengan data investasi ke daerah pasca pembatalan Perda. Sebab harapan dar pembatalan Perda, di antaranya, adalah memperlancar arus ineveatasi ke daerah karena kemudahan peraturan di daerah. Ini sejalan dengan Paket Ekonomi yang dilakukan oleh pemeritah Jokowi-JK sejak tahun 2015. Mengapa demikian? Ini karena sebagian besar (sekitar 52\%) pembatalan Perda yang dilakukan oleh Kemendagri terkait dengan hambatan investasi. Oleh karena itu, pembatalan Perda baru dapat dinilai dampaknya setelah 2 atau 3 semester ke depan; apakah lebih besar keuntungan yang diperoleh oleh daerah (melalui investasi yang semakin besar ke daerah karena didorong oleh kemudahan aturan, atau sebaliknya). Karenanya, evaluasi pembatalan Perda perlu dilakukan untuk membuktikan kesalahan asumsi pimpinan daerah dalam menilai pembatalan 3.142 Perda. 
Setarikan nafas dengan elaborasi alinea sebelumnya dan merujuk data pertumbuhan ekonomi per wilayah (regional) dan provinsi di Indonesia (lihat Gambar 1) tampak terjadi penurunan berarti pada Kwartal II tahun 2015. Di Sumatera misalnya, pada Kwartal III tahun 2014 pertumbuhan ekonomi berada di angka 5.2, tetapi pada Kwartal II tahun 2015 angka tersebut turun menjadi 3.6. Hal yang sama terjadi di region Jawa dan Kalimantan. Ini berbeda dengan Kawasan Timur Indonesia (KTI) yang justru mengalami pertumbuhan cukup signifikan. Hal ini menjelaskan apa? Dapat dilihat pada gambar sebagai berikut:

Gambar 1 Pertumbuhan ekonomi per regional dan provinsi di Indonesia

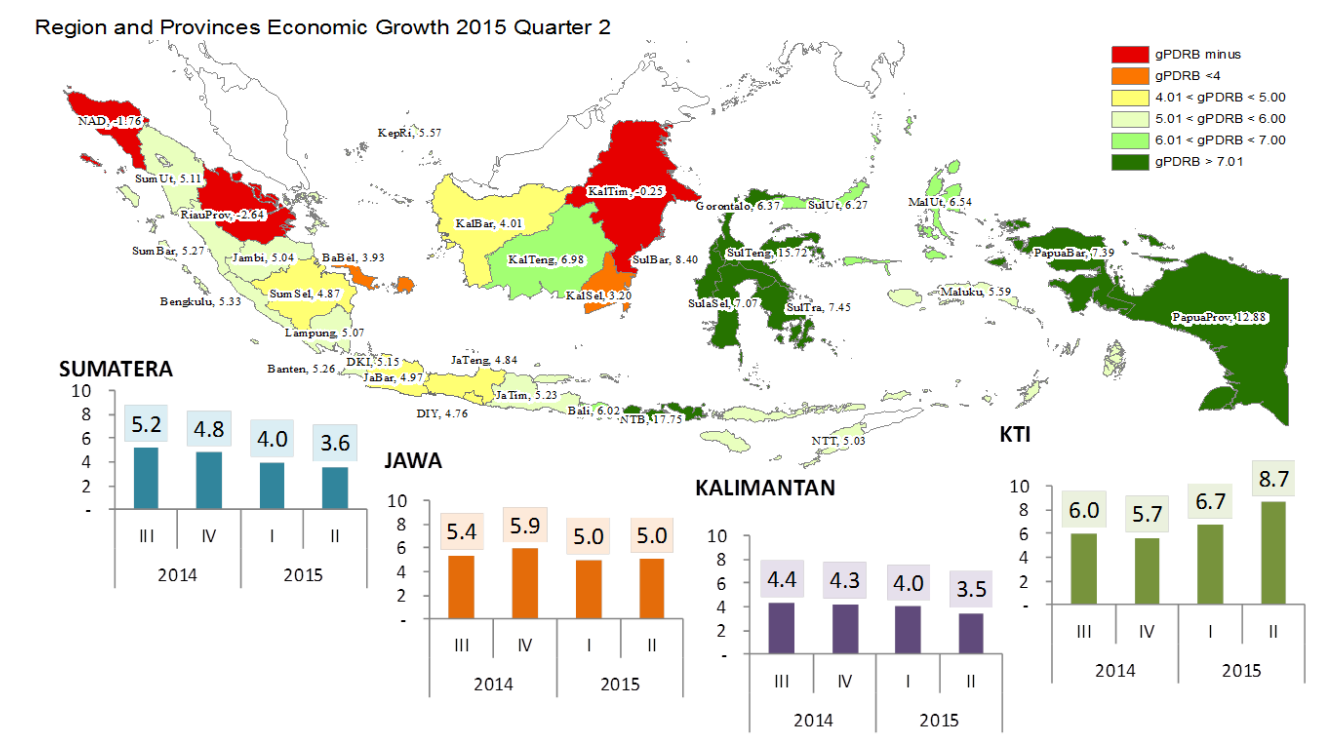

Sumber: diolah oleh Penulis dari data Bank Indonesia

Perbedaan pertumbuhan ekonomi antara Sumatera, Jawa, dan Kalimantan, serta KTI patut diperhatikan sebab terjadi pertumbuhan yang minus di beberapa daerah di Sumatera (Aceh dan Riau) dan Kalimantan (Kalimantan Timur, Kaltim). Ini aneh, sebab Aceh, Riau, dan Kaltim adalah daerah produsen mineral, tetapi pertumbuhan ekonominya minus (sekali lagi lihat Gambar 1). Pertanyaannya, mengapa terjadi pertumbuhan yang minus?
Jika dikaitkan dengan studi kebijakan, maka boleh jadi hal tersebut disebabkan oleh regulasi daerah yang justru tidak mendorong terhadap pertumbuhan ekonomi atau anti-growth (bisa dalam bentuk nontarrief barrier (NTB), biaya jasa berlebihan, dan macam sebagainya).

Asumsi lain yang dapat dibangun untuk menjelaskan pertanyaan tersebut di atas, setidaknya dapat dirujuk pada Grafik 1 (di bawah). Pada grafik tersebut 
tampak bahwa sejak tahun Juli 2009

(bahkan sebelumnya) hingga

Desember 2010, pertumbuhan

ekonomi di Indonesia mengalami

pertumbuhan yang signifikan.

Seperti diketahui bersama, sepanjang tahun 2002 hingga tahun 2009,

Kementerian Dalam Negeri

(Kemendagri) melakukan

pembatalan terhadap 2.246 Perda di seluruh Indonesia, bila dikaitkan dengan Grafik 1 ini, maka boleh jadi peningkatan pertumbuhan ekonomi tersebut disebabkan oleh pembatalan ribuan Perda itu. Namun sayangnya, Kemendagri tidak memiliki kajian komprehensif dan mendalam yang dapat menjelaskan hubungan tersebut sehingga klaim penulis masih bersifat hipotetikal. Tetapi paling tidak, jika berusaha dikait-kaitkan, maka boleh jadi ada kaitan antara pembatalan ribuan Perda tersebut dengan pertumbuhan ekonomi pada rentang itu.

Meski begitu, pada Desember 2010 terjadi titik balik, di mana pertumbuhan ekonomi yang signifikan pada periode sebelumnya secara perlahan mengalami penurunan berarti. Padahal antara tahun 2010 hingga tahun 2014 Kemendagri masih tetap melakukan pembatalan Perda-jumlahnya 1.501 Perda. Lantas persoalannya, jangan-jangan tidak ada hubungan antara pembatalan Perda dengan pertumbuhan ekonomi?

Inilah yang masih menjadi pertanyaan serius lagi hipotetikal, apakah pembatalan Perda yang dilakukan oleh Kemendagri tidak terkait dengan regulasi yang antiinvestasi sehingga tidak berimpak pada pertumbuhan ekonomi? Atau ada logika politik lokal yang memaksa pembatalan Perda tidak berdampak apa-apa. Logika politik lokal yang dimaksud adalah penyelenggaraan Pilkada langsung, di mana keuangan daerah, sumber daya alam, dan lainnya diproyeksikan untuk kepentingan elit dan pegembalian modal politik sehingga pembatalan Perda benarbenar tidak mendorong investasi dan pertumbuhan ekonomi. Oleh karena itu, perlu kiranya dilakukan penelitian yang mendalam dan intensif guna memahami fenomena ini. 
Grafik 1 Pertumbuhan Ekonomi di Indonesia

\section{Economic Growth Quarterly yoy (\%)}

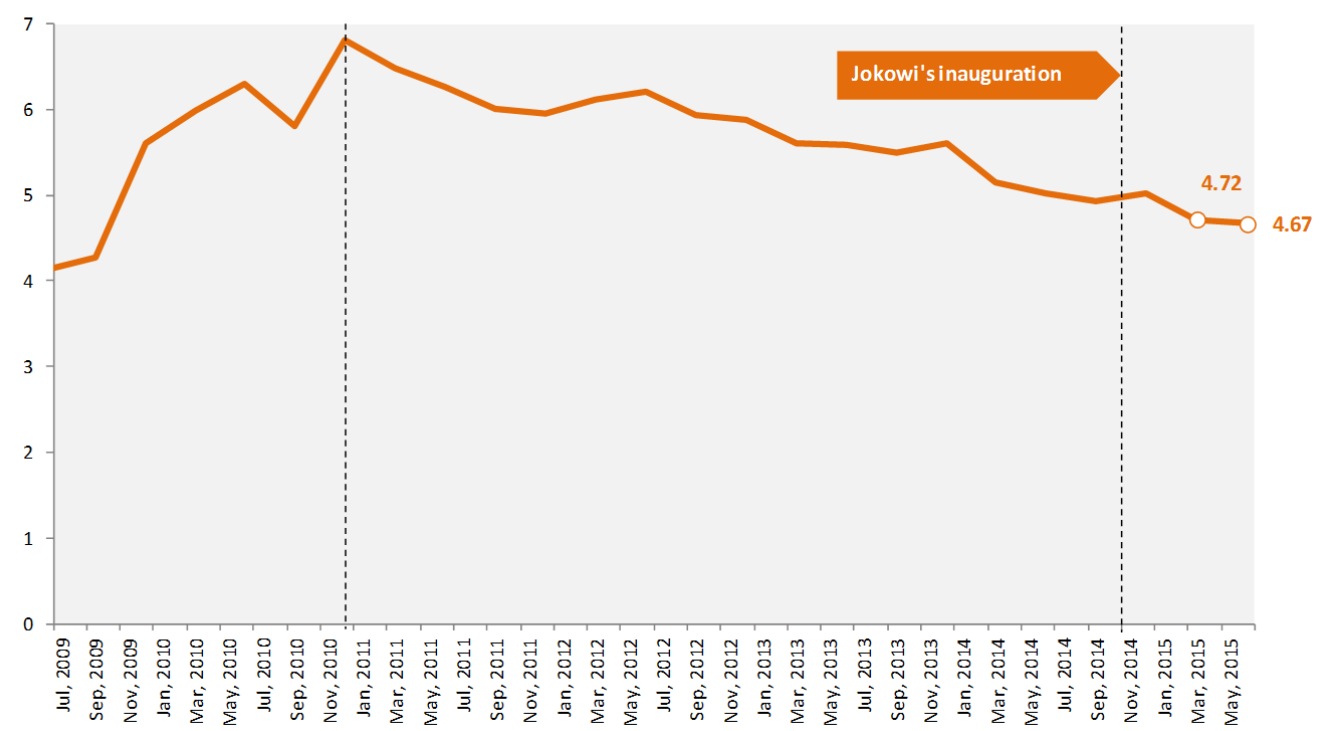

Sumber: diolah oleh Penulis dari data BPS

Menyitir Grafik 1 di atas, tampak bahwa terjadi penurunan yang pasti selepas Jokowi dilantik menjadi presiden RI ke-7 (Oktober 2014). Kendati begitu, penurunan tersebut tidak bisa begitu saja dianggap sebagai akibat dari kinerja yang kurang optimal. Ada sebab lain yang dapat dianggap sebagai sumber utama penurunan ekonomi nasional, di antaranya perlambatan ekonomi global pada tahun 2008 dan 2011 yang memporak-porandakan perekonomian Eropa (beberapa negara mengalami defisit anggaran neraca berjalan dan kebangkrutan seperti Yunani, Spanyol, Italia, Portugal, dan lainnya) serta beberapa negara Amerika Selatan termasuk Asia. Pun demikian, perekonomian lokal seharusnya tidak terlalu terpapar dampak ekonomi global tersebut. Seharusnya yang amat mempengaruhi perekonomian daerah adalah regulasi nasional dan lokal yang berdasar pada pendekatan institusional (melalui regulasi yang pro-invetasi dan pro-rakyat).

Pembatalan Perda ke depan harus diperdalam skopnya, tidak hanya kebijakan yang berada di bawah Kemendagri saja, tapi juga di bawah kementerian lain yang terkait dengan hambatan investasi, pungutan bermasalah, kelestarian lingkungan, efektfitas birokrasi, transparansi dan akuntabilitas, serta lainnya. Ini karena pembatalan Perda seharusnya bukan saja berhasil mendorong pertumbuhan ekonomi di daerah otonom, tapi lebih jauh dari itu, yakni dapat menurunkan tingkat pengangguran - yang berimplikasi secara langsung pada peningkatan 
Indeks Pembangunan Manusia (IPM). Data Bagan 1 (di bawah) memperlihatkan bahwa di daerah padat penduduk seperti di Jawa, tingkat pengangguran begitu tinggi, termasuk di daerah-daerah yang Perda-nya banyak dibatalkan seperti di Sumatera Utara (Sumut), Sumatera Selatan (Sumsel), Sulawesi Selatan (Sulsel), dan lainnya.

Bagan 1 Pengangguran terbuka per Agustus 2015

(dalam ribuan)

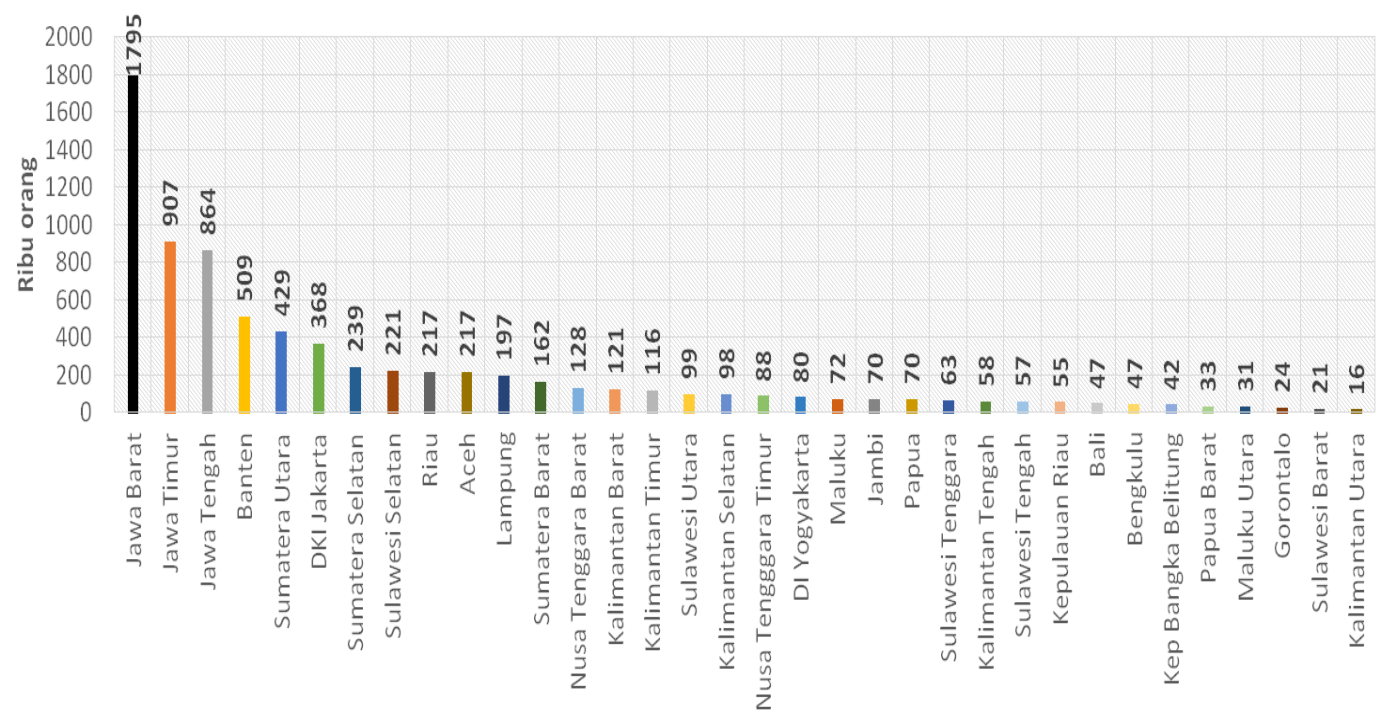

Sumber: diolah oleh Penulis dari data BPS

Realitas yang dibincangkan dalam bagian ini menunjukkan bahwa reaksi, tuntutan, atau gugatan daerah terkait dengan pembatalan Perda yang dihubungkan dengan hilangnya potensi PAD daerah masih perlu dilakukan kajian yang mendalam dan serius. Klaim hilangnya potensi PAD hingga puluhan miliar tidak bisa dikatakan begitu saja tanpa ada kajian akademik yang dapat dipertanggungjawabkan. Dan satu yang paling penting bahwa belum ada bukti kuat dengan dilakukannya pembatalan Perda di seluruh pemerintah daerah di Indonesia telah menurunkan perekonomian daerah. Oleh karena itu, perlu dilakukan evaluasi atau penilaian yang akademik pada Semester II atau III (setelah pelaksanaan pembatalan Perda ini) untuk memahami sejauhmana pembatalan Perda tersebut berdampak pada pertumbuhan ekonomi, peningkatan investasi (dalam negeri maupun asing), perbaikan pelaksanaan good governance, dan yang terpenting hadirnya indeks kebahagiaan warga.

LEGALITAS PEMBATALAN PERATURAN DAERAH 


Peraturan Daerah Provinsi
adalah peraturan perundang-
undangan yang dibuat atau dibentuk
oleh Dewan Perwakilan Rakyat
Daerah (DPRD) Provinsi dengan
persetujuan bersama Gubernur.
Manakala, Peraturan Daerah
Kabupaten/Kota adalah peraturan perundang-undangan yang dibentuk oleh DPRD Kabupaten/Kota dengan persetujuan bersama Bupati/Wali Kota. Materi muatan Peraturan Daerah Provinsi dan Kabupaten/Kota adalah materi muatan dalam rangka penyelenggaraan otonomi daerah dan tugas perbantuan serta menampung kondisi khusus daerah dan/atau penjabaran lebih lanjut peraturan perundang-undangan yang lebih tinggi.

Mengenai kedudukan

Peraturan Daerah Provinsi dan Kabupaten/Kota dalam hierarki peraturan perundang-undangan dapat dilihat pada Pasal 7, Undang-undang No. 12 tahun 2011 tentang Pembentukan Peraturan Perundangan-undangan, seperti berikut:

i. Undang-undang Dasar Negara Republik Indonesia Tahun 1945;

ii. Ketetapan Majelis Permusyarwaratan Rakyat (TAP MPR);

iii. Undang-undang/Peraturan Pemerintah Pengganti Undangundang (UU/Perppu);

iv. Peraturan Pemerintah (PP);

v. Peraturan Presiden (Perpres);

vi. Peraturan Daerah Provinsi; dan vii. Peraturan

Daerah

Kabupaten/Kota.

Merujuk pada jenis peraturan perundang-undangan, maka kekuatan hukum suatu peraturan perundangundangan sesuai dengan hierarkinya. Ini sejalan dengan asas 'kesesuaian antara jenis, hierarki, dan materi muatan,' yang mengandung arti peraturan perundang-undangan harus memperhatikan materi muatan yang tepat sesuai dengan jenis dan hierarki (lex superiori derogat legi inferiori; peraturan yang lebih tinggi mengesampingkan peraturan yang lebih rendah). Dalam arti kata lain, peraturan yang lebih rendah tidak boleh bertentangan (disharmoni) dengan peraturan yang lebih tinggi.

Pertanyaannya, bagaimana kalau ada Peraturan Daerah Provinsi dan Kabupaten/Kota bertentangan dengan undang-undang? Dan bagaimana pula jika ada Peraturan Daerah

Kabupaten/Kota bertentangan dengan Peraturan Daerah Provinsi? Siapakah yang berhak membatalkannya? Untuk menjawabnya, maka perlu penjelasan-penjelasan sebagai berikut.

Pertama, merujuk Undangundang No. 23 tahun 2014 tentang Pemerintahan Daerah, pembatalan Peraturan Daerah (Perda) dan Peraturan Kepala Daerah (Perkada) didasarkan pada Pasal 250, Ayat (1) yang mengamanahkan Perda dan Perkada dilarang bertentangan dengan ketentuan peraturan 
perundang-undangan yang lebih tinggi, kepentingan umum, dan/atau kesusilaan. Dan, kepentingan umum yang dimaksud (pada Ayat (2)) meliputi:

i. terganggunya kerukunan antarwarga masyarakat;

ii. terganggunya akses terhadap pelayanan publik;

iii. terganggunya ketenteraman dan ketertiban umum;

iv. terganggunya kegiatan ekonomi untuk meningkatkan

kesejahteraan masyarakat; dan/atau

v. diskriminasi terhadap suku, agama dan kepercayaan, ras, antar-golongan, dan gender.

Merujuk Pasal 250, Ayat (1) dan (2) di atas, maka dapat disimpulkan bahwa pembatalan Perda atau Perkada didasarkan atas tiga hal: (i) disharmoni kebijakan yang lebih tinggi, (ii) kepentingan umum, dan/atau (iii) kesusilaan.

Kedua, siapakah yang membatalkan Perda atau Perkada Provinsi? Merujuk Pasal 251, Ayat (1), disebutkan: "Perda Provinsi dan peraturan gubernur yang bertentangan dengan ketentuan peraturan perundang-undangan yang lebih tinggi, kepentingan umum, dan/atau kesusilaan dibatalkan oleh Menteri." Seturut itu, Pembatalan Perda Provinsi dan peraturan gubernur sebagaimana dimaksud pada ayat (1) ditetapkan dengan keputusan Menteri (Kepmen) (Pasal 251, Ayat (4)).
Ketiga, siapa yang membatalkan Perda atau Perkada Kabupaten/Kota? Merujuk Pasal 91, Ayat (1), disebutkan bahwa: "Dalam melaksanakan pembinaan dan pengawasan terhadap penyelenggaraan Urusan Pemerintahan yang menjadi kewenangan Daerah kabupaten/kota dan Tugas Pembantuan oleh Daerah kabupaten/kota, Presiden dibantu oleh gubernur sebagai wakil Pemerintah Pusat." Dilanjutkan Ayat (2) bahwa dalam melaksanakan pembinaan dan pengawasan sesuai pada Ayat (1), maka gubernur mempunyai tugas di antaranya (lihat Poin e), yakni: "Melakukan pengawasan terhadap Perda." Sejalan dengan itu, pada Ayat (3) ditegaskan bahwa: "Dalam melaksanakan tugas sebagaimana dimaksud Ayat (2), gubernur sebagai wakil Pemerintah Pusat mempunyai wewenang:" (salah satunya) adalah (lihat Poin a), "Membatalkan Perda Kabupaten/Kota dan peraturan bupati/wali kota." Maka dalam hal ini, gubernur (sebagai wakil pemerintah pusat) mempunyai wewenang untuk membatalkan Perda dan Perkada.

Di samping itu, kewenangan gubernur untuk membatalkan Perda Kabupaten/Kota juga termaktub dalam Pasal 251, Ayat (2) yang menyebutkan: "Perda Kabupaten/Kota dan peraturan bupati/wali kota yang bertentangan dengan ketentuan peraturan 
perundang-undangan yang lebih tinggi, kepentingan umum, dan/atau kesusilaan dibatalkan oleh gubernur sebagai wakil Pemerintah Pusat."

Pada dua paragraf di atas jelas bahwa pembatalan Perda dan Perkada di tingkat Kabupaten/Kota dilakukan oleh Gubernur sebagai wakil pemerintah pusat di daerah. Namun, apabila Gubernur sebagai wakil Pemerintah Pusat tidak membatalkan Perda Kabupaten/Kota dan/atau peraturan bupati/wali kota (Perkada) yang bertentangan dengan ketentuan peraturan perundangundangan yang lebih tinggi, kepentingan umum, dan/atau kesusilaan (sebagaimana dimaksud pada Pasal 250, Ayat (2)), maka merujuk Pasal 251, Ayat (3), Menteri dapat membatalkan Perda Kabupaten/Kota dan/atau peraturan bupati/wali kota berkenaan.

Keempat, merujuk Pasal 24A

Ayat (1) UUD NRI 1945 menyatakan bahwa, "Mahkamah Agung berwenang mengadili pada tingkat kasasi, menguji peraturan perundang-undangan di bawah undang-undang terhadap undangundang, dan mempunyai wewenang lainnnya yang diberikan oleh undang-undang." Berdasarkan ketentuan ini, dapat dipahami bahwa apabila terdapat suatu Perda yang bertentangan dengan undang-undang, maka lembaga yang diberikan kewenangan untuk menguji dan membatalkannya adalah Mahkamah Agung. Hal ini diperkuat oleh Pasal
9, Ayat (2), Undang-Undang No. 12 tahun 2011 tentang Pembentukan Peraturan Perundang-undangan menyebutkan bahwa, "Dalam hal suatu Peraturan Perundang-undangan di bawah Undang-Undang diduga bertentangan dengan UndangUndang, pengujiannya dilakukan oleh Mahkamah Agung."

Poin keempat ini dapat memicu polemik, sebab di satu sisi, poin pertama hingga ketiga mewenangkan Mendagri untuk membatalkan Perda, tapi pada poin keempat, MA-lah lembaga yang pantas membatalkannya. Hal ini menunjukkan terjadi disharmonisasi antara peraturan perundangundangan yang mengatur tentang legalitas pembatalan Perda, antara Undang-undang No. 12 tahun 2011 dengan Undang-undang No. 23 tahun 2014. Pertanyaannya, undangundang mana yang harus diikuti atau patuhi?

Adagium hukum mengatakan bahwa suatu peraturan perundangundangan masih dianggap berlaku sebelum ada undang-undang yang mencabutnya sehingga kedua undang-undang tersebut dapat dijadikan pembenar (justify) dalam pembatalan Perda. Tapi, untuk menjawab pertanyaan di atas, tentu harus mengacu pada kaidah-kaidah penyusunan perundang-undangan yang berlaku. Dalam kaidah penyusunan perundang-undangan, jika terjadi disharmonisasi antara peraturan perundang-undangan 
setingkat, hal yang harus diperhatikan adalah siapa pemberi mandat undang-undang tersebut. Jika pembentukan salah satu undangundang di antara undang-undang yang bertentangan merupakan amanat langsung dari UUD NRI 1945, maka undang-undang tersebutlah yang seharusnya dijadikan tempat berpijak utama dalam kehidupan berhukum di Indonesia. Jika hal ini dikontekstualisasi dengan polemik mengenai legalitas Mendagri dalam mencabut Perda, maka secara normatif Mendagri memiliki legalitas dalam pembatalan Perda karena berpayung pada dalam Pasal 251 Undang-undang No. 23 tahun 2014 tentang Pemerintahan Daerah.

Di luar itu semua, sebagai pengecualian Perda Pajak dan Retribusi Daerah, sebagaimana diatur dalam Undang-undang No. 28 tahun 2009 tentang Pajak Daerah dan Retribusi Daerah, Menteri Keuangan dapat memberikan rekomendasi pembatalan Perda kepada Menteri Dalam Negeri.

\section{PEMBATALAN PERDA: KLUSTER DAN PROVINSI}

Pada bagian awal sudah disebutkan bahwa dasar pembatalan Perda terdiri atas empat hal: (i) Perda dan Perkada tersebut menghambat investasi; (ii) Perda dan Perkada tersebut bertentangan dengan undang-undang yang lebih tinggi dan kepentingan umum; (iii) Perda dan
Perkada bertentangan dengan UU No. 23 tahun 2014 tentang Pemerintahan Daerah dan Putusan Mahkamah Konstitusi; dan (iv) Perda dan Perkada lainnya yang dirasa tidak perlu karena merupakan norma awam yang berlaku di masyarakat, maka pada bagian ini dianalisis pengklusteran lebih rinci atas peraturan-pertauran daerah bermasalah secara lebih rinci. Setidaknya ada 15 kluster yang dapat digunakan untuk mempermudah pembagian jenis Perda yang dibatalkan: ${ }^{6}$

i. Mineral, Gas, Tambang, dan Batubara

ii. Pajak

iii. Retribusi

iv. HIV dan Kesusilaan

v. Penyelenggaraan Adminsitrasi Kependudukan

vi. Pertanian dan Perkebunan

vii. Pengelolaan Barang Milik Daerah

viii. Sumber Daya Air dan Irigasi

ix. Izin Gangguan

x. Badan Usaha Milik Daerah (BUMD)

xi. Izin tertentu (Izin Usaha, IMB, dan lainnya)

xii. Penyelenggaraan Urusan

Provinsi dan Kabupaten/Kota

\footnotetext{
${ }^{6}$ Kemendagri menggunakan lima kategori yakni: (i) Retribusi Jasa Umum, (ii) Implikasi Putusan MK, (iii) Pelayanan Publik, (iv) Konsekuensi peralihan urusan pemerintahan daerah, dan (v) lain-lain yang meliputi penulisan legal drafting hingga delegasi blanko.
} 
xiii. Penyelenggaraan Pendidikan, TKI, dan Hak Anak

xiv. Jasa Pelayanan Tera, Alat Ukur, dan Timbangan

xv. Pengelolaan Ketenagalistrikan

xvi. Sumbangan Periode 3 pada Pemerintah

Merujuk pada kluster tersebut, maka dapat disimpulkan beberapa hal. Pertama, dari 1.765
Perda (baik di tingkat Provinsi mapun Kabupaten/Kota) yang dicabut/direvisi oleh Menteri Dalam Negeri (Mendagri), retribusi adalah Perda yang paling banyak dibatalkan (745 Perda), disusul dengan Pajak (279 Perda), Pengelolaan Barang Milik Daerah (184 Perda), hingga yang terendah HIV dan Kesusilaan (2 Perda) (lihat Bagan 2).

Bagan 2 Pembatalan 1.765 Perda (per Kluster)

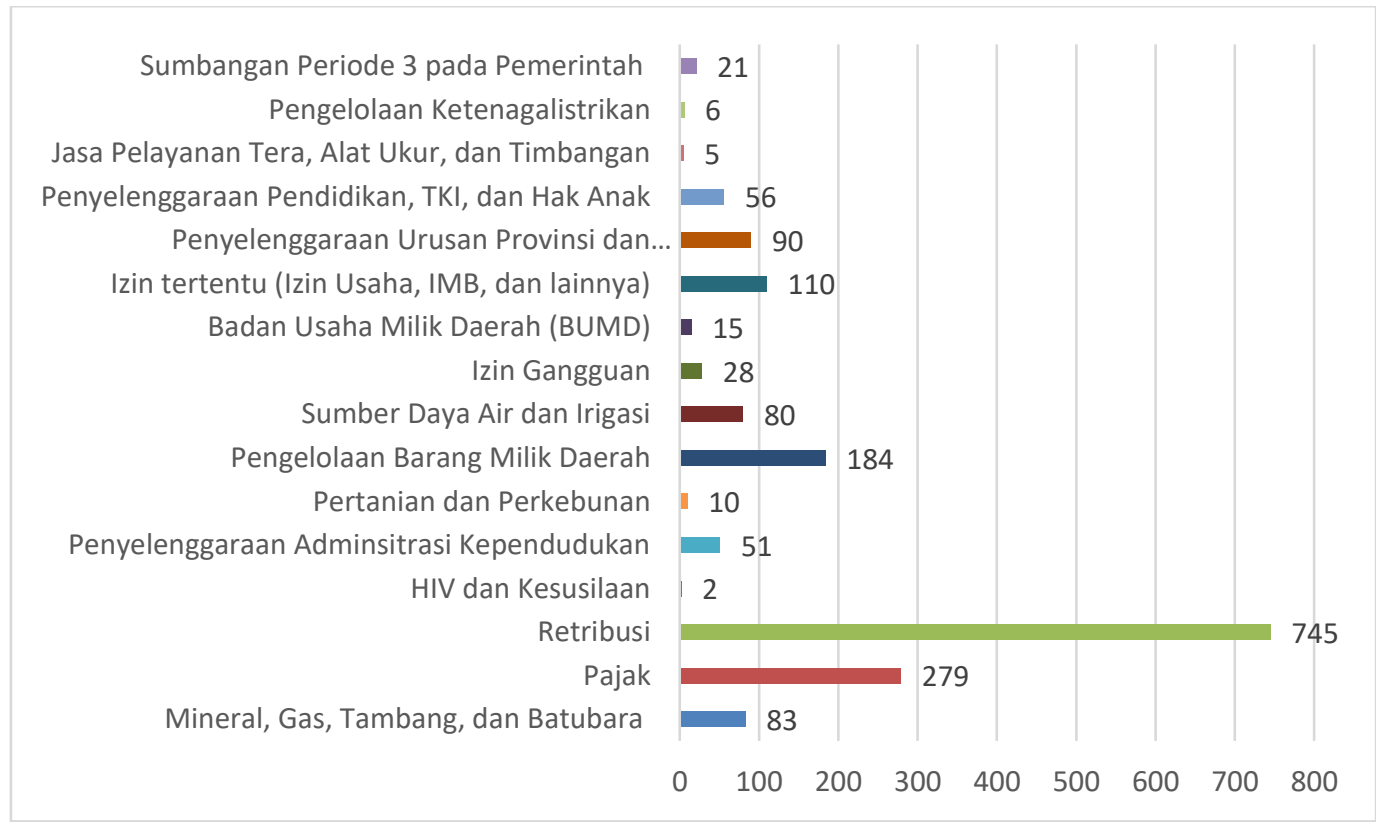

Sumber: diolah oleh Penulis dari Kemendagri (2017)

Mengapa banyak Perda retribusi dibatalkan? Ini karena di banyak daerah retribusi kerap bersifat pajak. Padahal konsep retribusi adalah user-benefit charges atau pertukaran dengan pembayaran harus menyediakan jenis jasa atau manfaat pada pembayarnya. Retribusi merupakan alat untuk membiayai penyediaan jasa tertentu dan bukan suatu mekanisme untuk meningkatkan PAD. Untuk menjamin terjadinya efisiensi dalam penyediaan jasa, maka pendapatan yang berhasil dikumpulkan dari retribusi tertentu harus habis digunakan untuk menyediakan jasa tersebut. Juga untuk menjamin hubungan pembayaran-manfaat, pendapatan yang diterima seharusnya dipegang oleh badan yang memberikan jasa tersebut, daripada 
mentransfer kepada Dispenda (Dinas Pendapatan Daerah) setempat.

Berikutnya disusul dengan pajak yang berjumlah 279 Perda. Sebagian besar dari Perda pajak yang dibatalkan lebih bernuansa pemberatan pada subjek pajak sehingga memperlambat pertumbuhan ekonomi di daerah. Pajak daerah semestinya tidak ditegakkan pada objek yang mempunyai mobilitas tinggi. Objek pajak pada tingkat rendah sebaiknya diarahkan pada objek yang bermobilitas rendah (contohnya properti dan gedung, lampu, spanduk, hotel, restoran, dan lain sebagainya). Hal ini sekaligus menjamin kebebasan pergerakan barang dan jasa antar-daerah.

Merujuk pada dua kluster ini (retribusi dan pajak), dalam bahasa umum disebut sebagai "pungutan" (jika ditotal jumlah keduanya 1.024 Perda), maka secara umum dapat disimpulkan bahwa $58 \%$ pembatalan Perda mengarah pada masalah pungutan; dan ini belum terkait dengan Perda "Izin Tertentu" yang berjumlah 110. Bila ketiga kluster ini digabungkan, maka akan berjumlah 1.134 Perda yang setara dengan 64,2\% dari 1.765 Perda yang dibatalkan oleh Menteri Dalam Negeri (Mendagri). Kluster retribusi dan pajak (serta izin tertentu) inilah yang menurut Kemendagri memperlambat pertumbuhan ekonomi daerah, oleh karenanya, layak untuk dibatalkan. Dengan pembatalan ini, diharapkan roda ekonomi bergerak dengan lancar dan investasi dapat masuk secara mudah.

Kedua, mengenai peralihan kewenangan sebagai mandat Undang-undang No. 23 tahun 2014 seperti pendidikan (56 Perda), Minerba (83 Perda), serta penyelenggaraan urusan provinsi dan kabupaten/kota (90 Perda) misalnya, di mana total gabungan kluster tersebut berjumlah 229 Perda (atau setara dengan 12,9\%), menunjukkan angka yang moderat berbanding pembatalan Perda pungutan. Meski demikian, Perda tersebut harus dibatalkan karena sudah tidak sesuai lagi dengan kewenangan yang sudah beralih ke atasnya.

Ketiga, merujuk Bagan 3 di bawah, Pembatalan Perda dapat dibagi ke dalam tiga kategori: (i) pembatalan Perda dengan kuantitas tinggi, (ii) pembatalan Perda dengan kuantitas sedang, dan (iii) pembatalan Perda dengan kuantitas tinggi. Jawa Timur, Jawa Barat, Sumatera Utara, dan Sulawesi Selatan adalah provinsi yang terkategori dalam pembatalan Perda dengan kuantitas tinggi (Jawa Timur (142 Perda), Jawa Barat (136 Perda), Sumatera Utara (133 Perda), dan Sulawesi Selatan (121 Perda)). Kalimantan Tengan, Kalimantan Barat, Kalimantan Selatan, Kalimantan Timur, Aceh, Sumatera Barat, Sumatera Selatan, Riau, dan Nusa Tenggara Barat terkategori dalam pembatalan Perda dengan 
kuantitas sedang (Kalteng (73 Perda), Kalbar (69 Perda), Kalsel (67 Perda), Kaltim (66 Perda), Aceh (65 Perda), Sumbar (60 Perda), Sumsel (60 Perda), Riau (53 Perda), dan NTB (53 Perda)). Dan provinsi lainnya terkategori dalam pembatalan Perda dengan kuantitas rendah.

Pembatalan Perda dengan kuantitas tinggi berlaku di provinsiprovinsi dominan seperti Jawa Timur, Jawa Barat, Sumatera Utara, dan Sulawesi Selatan. Jawa Timur dan Jawa Barat dianggap memiliki jumlah penduduk besar di Jawa, Sumatera Utara dianggap sebagai pusat perekonomian besar di Sumatera, begitu juga dengan Sulawesi Selatan. Oleh karena itu, tidak heran apabila daerah-daerah berusaha untuk mengatur daerahnya melalui regulasi daerah yang berorientasi pada kepentingan publik.
Namun, penilaian Kemendagri berbeda. Sebab itulah, maka pembatalan Perda dilakukan pada daerah-daerah yang simpul ekonomi di Jawa, Sumatera, dan Sulawesi. Sementara Pembatalan Perda dengan kuantitas sedang terjadi provinsiprovinsi layer kedua di Indonesia. Jadi kesimpulannya, peraturan-peraturan daerah yang dibatalkan ternyata mengikuti pola pertumbuhan ekonomi di suatu provinsi (kecuali DKI Jakarta), jumlah penduduk, dan mobilitas masyarakat. Ini dibuktikan dengan provinsi yang mengalami pembatalan Perda yang tinggi dan sedang (serta rendah) ternyata adalah provinsiprovinsi simpul di Indonesia. Misalnya, Sumatera Utara di Sumatera, Sulawesi Selatan di Sulawesi, dan Jatim dan Jabar di Jawa. 
Bagan 3 Pembatalan 1.765 Perda (per Provinsi)

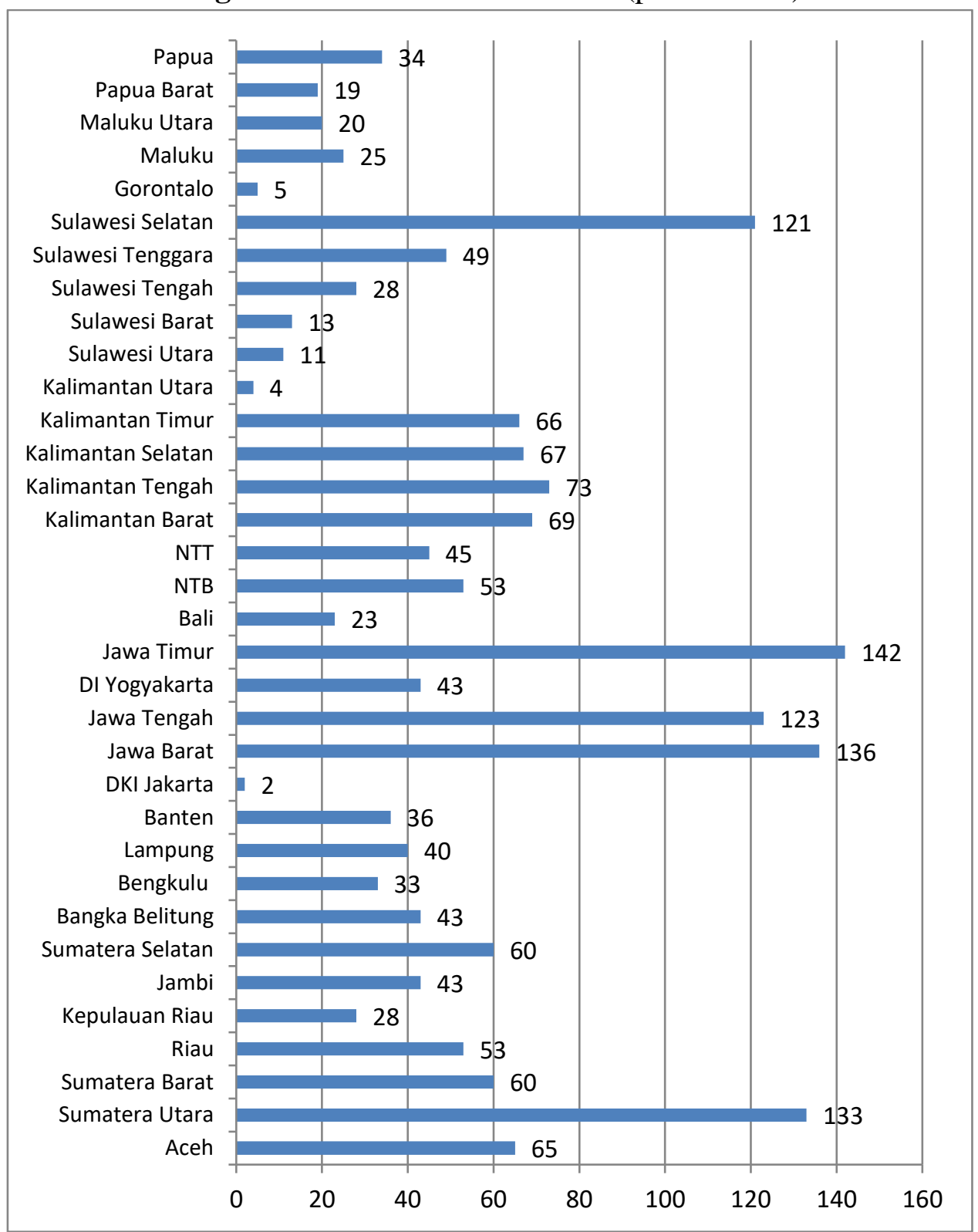

Sumber: dioleh oleh Penulis dari Kemendagri (2017)

Keempat, jika pada poin pertama, terdapat 1.765 Perda (baik di tingkat Provinsi mapun Kabupaten/Kota) yang dicabut/direvisi oleh Menteri Dalam Negeri (Mendagri), maka pada bagian ini terdapat 1.267 Perda yang dicabut/direvisi oleh gubernur.
Merujuk Bagan 4, dapat disimpulkan bahwa kasus yang relatif sama juga terjadi pada bagian ini di mana retribusi adalah Perda yang paling banyak dibatalkan (411 Perda), disusul dengan Penyelenggaraan Urusan Provinsi dan Kabupaten/Kota (151 Perda), Pengelolaan Barang 
Milik Daerah (135 Perda), Pajak (125 Perda), dan seterusnya.

Manakala kluster terendah yang dibatalkan antaranya adalah HIV dan Kesusilaan serta Jasa Pelayanan Tera, Alat Ukur, dan Timbangan (masing-masing 1 Perda), Badan Usaha Milik Daerah (BUMD) (7 Perda), Pengelolaan Ketenagalistrikan (8 Perda), dan lainnya (lihat Bagan 4 di bawah).

Dalam konteks ini, hal yang sama dapat dijelaskan bahwa Perda yang dibatalkan lbih mengarah pada
Perda retribusi yang salah tujuan. Maksudnya, retrisbusi tidak dipungu sebagaimana mestinya, tetapi ia dipungut yang sejalan dengan fungsi pajak. Oleh karena itu, patut dibatalkan. sementara itu, pembatalan Perda terkait dengan Penyelenggaraan Urusan Provinsi dan Kabupaten/Kota lebih disebabkan oleh peralihan urusan dari kabupaten/kota ke provinsi atau pusat; karenanya gubernur membatalkan Perda-perda berkenaan.

Bagan 4 Pembatalan 1.267 Perda (per Kluster)

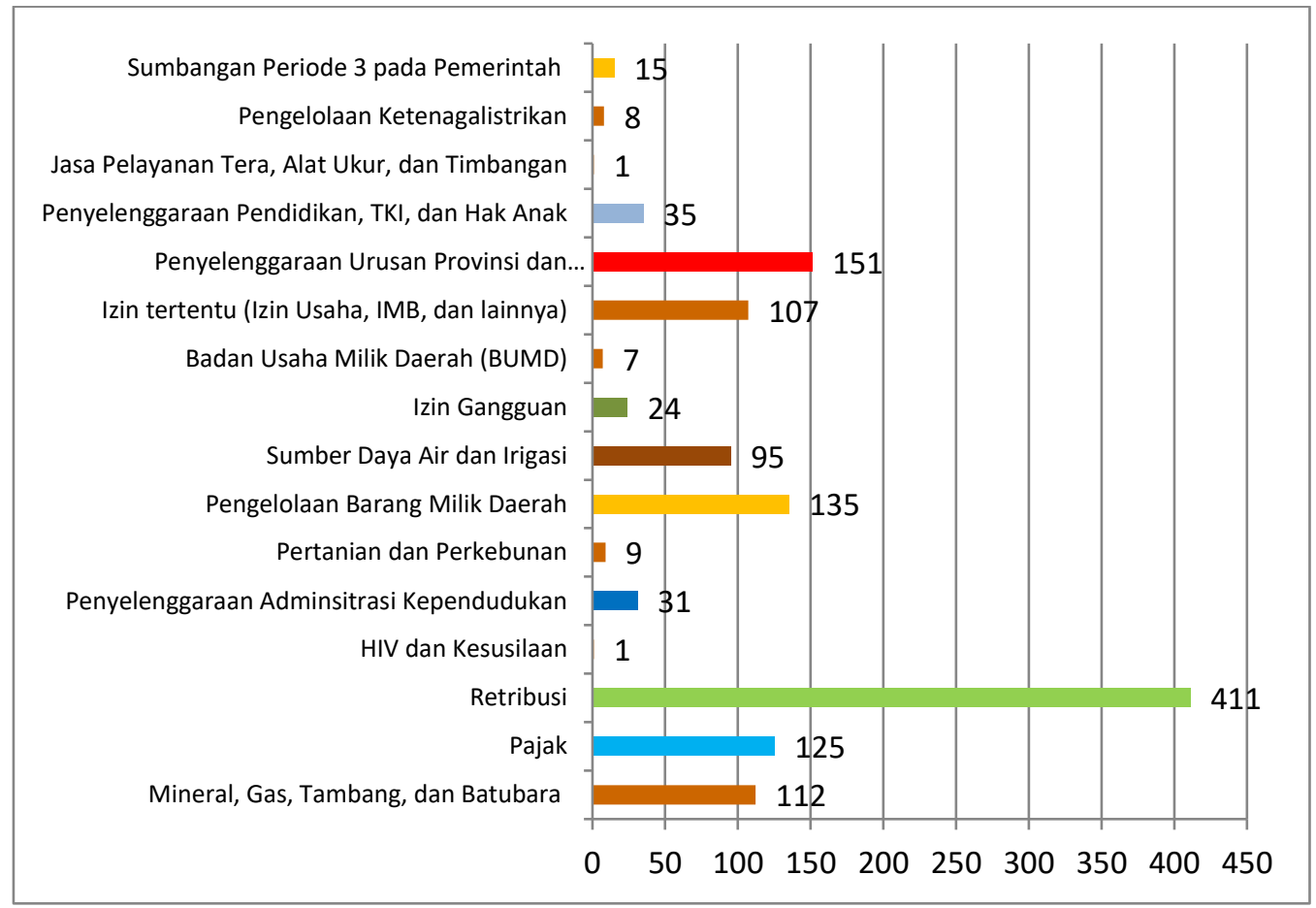

Sumber: diolah oleh Penulis dari Kemendagri (2017)

Kelima, pembatalan 1.267 Perda yang dilakukan gubernur menunjukkan pola yang berbeda dengan poin ketiga di atas. Pada bagian ini provinsi yang melakukan pembatalan tidak mengikut pola pertumbuhan ekonomi di suatu provinsi, jumlah penduduk, dan mobilitas masyarakat, tetapi lebih acak dari itu. Ini bisa dilihat dari 
urutan berikut (dimulai dari yang tertinggi): (i) Jawa Timur membatalkan 94 Perda, Jawa Tengah dan Maluku (84 Perda), Lampung dan Sumatera Barat (78 Perda), Bali (71 Perda), NTT (69 Perda),
Kalimantan Selatan (65 Perda), dan NTB (63 Perda) (lihat Bagan 5). Keunikan temuan ini patut dilakukan pendalaman kajian guna mendapatkan jawaban yang sesuai dengan kebutuhan pembatalan Perda.

Bagan 5 Pembatalan 1.267 Perda (per Provinsi)

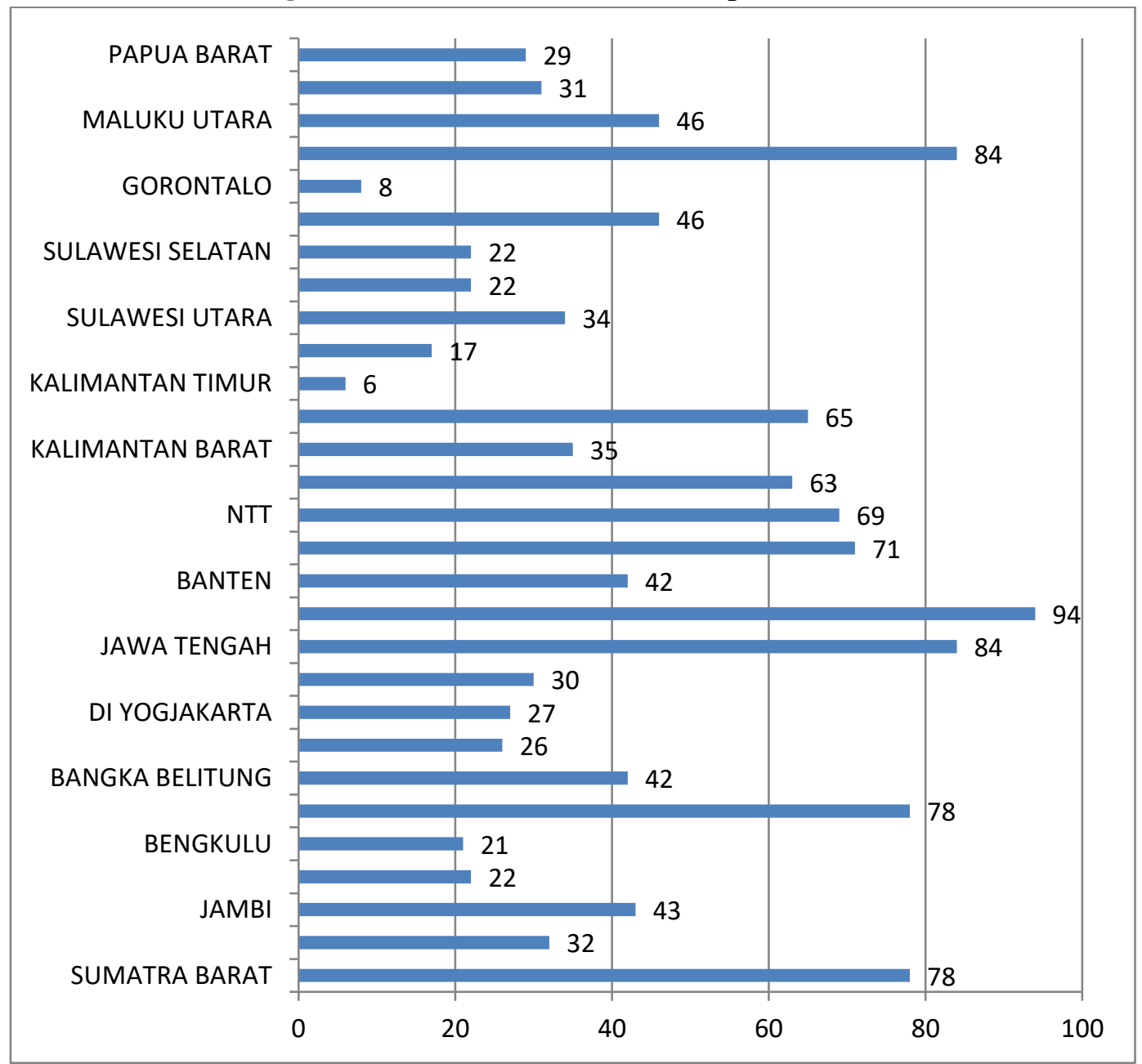

Sumber: diolah oleh Penulis dari Kemendagri (2017)

Menyitir Bagan 5 di atas, dapatlah disimpulkan beberapa hal. Pertama, pembatalan Perda oleh gubernur memang memerlukan 'keberanian' tersendiri (oleh gubenur sebagai wakil pemeirntah pusat). Ia harus berani menjadi pemimpin daerah yang tidak popular terutama dalam menegakkan aturan dalam rangka menghadirkan kesejahteraan bagi masyarakat luas. Kedua, komunikasi dan koodinasi menjadi kunci sukses dan keberhasilan gubernur untuk mengajak 
kabupaten/kota guna memahami kesalahan yang harus mereka lakukan dengan cara mencabut peraturan-peraturan daerah bermasalah. Ketiga, Perda pungutan harus ditimbang ulang kontennya agar investor mau menanamkan modalnya di daerah-dan tidak merasa diberatkan oleh banyak pungutan yang menyebabkan ekonomi biaya tinggi (high cost economy).

Secara keseluruhan, pembatalan 3.143 Perda memang harus dilakukan dalam rangka menegakkan aturan sebagaimana tertuang dalam Undang-undang No. 23 tahun 2014 dan Putusan MK, mendorong pertumbuhan ekonomi yang terus melambat sejak pelantikan Joko Widodo sebagai Presiden ke-7 Indonesia (lihat Grafik 1), dan 'menghadirkan kembali' otonomi daerah dalam kerangka Negara Kesatuan Republik Indonesia.

\section{DAFTAR PUSTAKA}

Agustino, L. 2014. Politik Lokal dan Otonomi Daerah. Bandung: Alfabeta.

Ali, K. 2002. Understanding decentralization: local power over decision-making for comprehensif planning in Florida. Disertasi PhD. Michigan University.

Escobar-Lemmon, M.C. 2000. The causes and process of decentralization. Disertasi
PhD. The University of Arizona.

Hoggart, K. 1981. Local decisionmaking autonomy: a review of conceptual and methodological issues. London: King's College Press.

Kementerian Dalam Negeri Republik Indonesia. 2016. Daftar Pembatalan Perda/Perkada dan Peraturan Menteri Dalam Negeri yang Dibatalkan. Jakarta: Kemendagri RI.

Rosenbloom, D.H. 1993. Public administrastion:

understanding management, politics, and law in the public sector. New York: McGrawHill.

Sammoff, J. 1990. Decentralization: the politics of intervention. Development and Change 21: 513-530.

Seabright, P. 1996. Accountability and decentralization in government: an incomplete contracts model. European Economics Review 40: 61-89.

Smith, B.C. 1985. Decentralization: the territorial dimension of the state. London: Allen \& Unwin.

Undang-undang No. 22 tahun 1999 tentang Pemerintahan Daerah. Undang-undang No. 25 tahun 1999 tentang Perimbangan Keuangan Pusat dan Daerah. 
Undang-undang No. 28 tahun 2009

tentang Pajak Daerah dan

Retribusi Daerah.

Undang-undang No. 12 tahun 2011

tentang Pembentukan

Peraturan Perundangan-

undangan.

Undang-undang No 23 tahun 2014

tentang Pemerintahan Daerah. 